\title{
THE PRODUCING OF LEAD AND ELEMENTAL SULFUR BY NEW TECHNOLOGIES FROM GALENITE ORES
}

\author{
Boris KRSTEV, \\ Faculty of natural \& technical sciences, UGD - Shtip, R. Macedonia \\ Alexandar KRSTEV, Dejan KRSTEV \\ Faculty of Informatics, UGD - Shtip, R. Macedonia
}

\begin{abstract}
These investigations have developed an effective hydrometallurgical method to recover highpurity lead metal and elemental sulfur from simulated galena synthetic mixures eliminating sulfur gases and lead emissions, in contrast to the current high-temperature smelting technology.

The method consists of different operations: oxidative leaching with production of solution with residue containing elemental sulfur., electrowinning by the solution with metal production.

The obtained results determined the optimal parameters for possible processing of natural domestic galena ores.
\end{abstract}

Keywords: leaching, lead, sulfur, synthetic mixures

\section{Introduction}

A major cost factor in the sintering and smelting process for producing $\mathrm{Pb}$ is the control needed to meet existing environmental standards for $\mathrm{Pb}$ emissions. Another issue is the current concern over acid rain, which will in all probability result in even more stringent controls on emission of sulfur gases.

Processing of the galena mixures or concentrates is developed as an effctive lowtemperature leaching-electrowining method to produce $\mathrm{Pb}$ metal and elemental sulfur from galena mixures or concentrates. The method reduces $\mathrm{Pb}$ emissions and totally eliminates the formation of sulfur gases. The elemental $S$ produced is more economical to store and ship than the sulfuric acid $\left(\mathrm{H}_{2} \mathrm{SO}_{4}\right)$ generated by the high-temperature smelting process.

This hydrometallurgical method consists of leaching galena synthetic mixures or concentrates in waste fluosilicic acid $\left(\mathrm{H}_{2} \mathrm{SiF}_{6}\right)$ with hydrogen peroxide $\left(\mathrm{H}_{2} \mathrm{O}_{2}\right)$ and lead dioxide $\left(\mathrm{PbO}_{2}\right)$ as oxidantsat $95^{\circ}$, electrowinning the
$\left(\mathrm{PbSiF}_{6}\right)$ solution at $35^{\circ}$ to produce $99,99 \% \mathrm{~Pb}$ metal, and solvent extraction to recover $\mathrm{S}$, leaving a residue containing eventually present $\mathrm{Cu}, \mathrm{Ag}$, and other metal values.

$$
\begin{gathered}
2 \mathrm{PbS}+3 \mathrm{H}_{2} \mathrm{SiF}_{6}+\mathrm{H}_{2} \mathrm{O}_{2}+ \\
\mathrm{PbO}_{2} \Rightarrow 3 \mathrm{PbSiF} 6+4 \mathrm{H}_{2} \mathrm{O}+2 \mathrm{~S}^{\circ} \\
\mathrm{PbSiF}_{6}+2 \mathrm{H}^{+}+2 e^{-} \Rightarrow \mathrm{Pb}+\mathrm{H}_{2} \mathrm{SiF}_{6}
\end{gathered}
$$

Several galena leaching processes have been investigated, including processing using ferric chloride, ferric sulfate, nitric acid and ammonium acelate solutions. The leached $\mathrm{PbCl}_{2}$ and $\mathrm{PbSO}_{4}$ salts have a very limited solubility in aqueos solution, making aqueos electrolysis difficult. Lead metal was recoverable from $\mathrm{PbCl}_{2}$ by molten-salt electrolysis operated at $450^{\circ}$. It's known that elecrowinning of $\mathrm{Pb}$ in $\mathrm{HNO}_{3}$ and $\mathrm{H}_{2} \mathrm{SiF}_{6}$ solutions yields $\mathrm{Pb}$ metal at the cathodes and at the same time $\mathrm{PbO}_{2}$ at the anodes.

The next text will explain the oxidative leaching-electrowinning process. The parameters 
for leaching process about synthetic mixures were investigated in laboratory experiments.

\section{General}

The chemical equations for $\mathrm{PbS}$ leaching in acid solution with and without oxidants follow:

$$
\begin{aligned}
& \mathrm{PbS}+2 \mathrm{H}^{+}+[\mathrm{O}] \Rightarrow \mathrm{Pb}^{2+}+\mathrm{S}^{\circ}+\mathrm{H}_{2} \mathrm{O} \\
& \mathrm{PbS}+8 \mathrm{H}^{+}+8[\mathrm{O}] \Rightarrow \mathrm{PbSO}_{4}+4 \mathrm{H}_{2} \mathrm{O} \\
& \mathrm{PbS}+2 \mathrm{H}^{+}+\Rightarrow \mathrm{Pb}^{2+}+\mathrm{H}_{2} \mathrm{~S}
\end{aligned}
$$

Reaction (3) shows that oxidative leaching of $\mathrm{PbS}$ will yield $\mathrm{Pb}$ salt and elemental $\mathrm{S}$. Reaction (4) suggests $\mathrm{PbSO}_{4}$ may form if the redox potenial of the solution is too high, and reaction (5) indicates $\mathrm{H}_{2} \mathrm{~S}$ will form when leaching in acid solution if the redox potential is too low. To avoid the generation of $\mathrm{H}_{2} \mathrm{~S}$ one-fourth of the required oxidant have to be added to the $\mathrm{H}_{2} \mathrm{SiF}_{6}$ solution prior to the addition to the $\mathrm{PbS}$. The reaction is exothermic and it's necessary to add $\mathrm{H}_{2} \mathrm{O}_{2}$ slowly through a birette to avoid overheating the leach solution. After adding the $\mathrm{H}_{2} \mathrm{O}_{2}, \mathrm{PbO}_{2}$ was added slowly to control the redox potential. The reacions occuring during the oxidative leaching of $\mathrm{PbS}$ synthetic mixures or concentrates with $\mathrm{H}_{2} \mathrm{SiF}_{6}$ are shown below. At the end of leaching, the mixture was filtered to separate the leachate from the residue. The residue consisted of elemental $\mathrm{S}$ and other metal values. The leachate is sent to electrowinning to recover pure $\mathrm{Pb}$ metal.

$\mathrm{PbS}+\mathrm{H}_{2} \mathrm{O}_{2}+\mathrm{H}_{2} \mathrm{SiF}_{6} \Rightarrow \mathrm{PbSiF}_{6}+2 \mathrm{H}_{2} \mathrm{O}+\mathrm{S}^{\circ}$

$\mathrm{PbS}+\mathrm{PbO}_{2}+\mathrm{H}_{2} \mathrm{SiF}_{6} \Rightarrow \mathrm{PbSiF}_{6}+\mathrm{PbO}+\mathrm{H}_{2} \mathrm{O}+\mathrm{S}^{o}(7)$

$\mathrm{PbO}+\mathrm{H}_{2} \mathrm{SiF}_{6} \Rightarrow \mathrm{PbSiF}_{6}+\mathrm{H}_{2} \mathrm{O}$

\subsection{Previous investigations}

As leaching parameters were investigated: $\mathrm{PbS}$ samples of $98 \%$ on the -400 mesh or $96 \%$ on the as-received concentrates if $\mathrm{H}_{2} \mathrm{O}_{2}$ and $\mathrm{PbO}_{2}$ were used as oxidants ( the possible oxidants may be air, oxygen, ozone, $\mathrm{HNO}_{3}$ and $\mathrm{MnO}_{2}$ ); leaching temperature from 50-95 ; leaching time from 35-335 min. The results of carried out investigations follow:

Table 1. Effect of various amounts of oxidants

\begin{tabular}{l|l|l|} 
Test & $\mathrm{H}_{2} \mathrm{O}_{2} 35 \%-m l$ & $\mathrm{PbO}_{2} \mathrm{gr}$.
\end{tabular}

$\mathrm{Pb} \%$

\begin{tabular}{|c|c|c|c|}
\hline 1 & 0,0 & 16,0 & 92,0 \\
2 & 2,5 & 17,0 & 95,0 \\
3 & 5,0 & 9,8 & 95,0 \\
4 & 7,5 & 8,1 & 96,8 \\
5 & 10,0 & 5,7 & 95,1 \\
6 & 19,0 & 0,0 & 96,0 \\
\hline
\end{tabular}

Table 2.Effect of time and temperature

\begin{tabular}{|c|c|c|c|}
\hline & \multicolumn{3}{|c|}{ Leach time } \\
\hline & $30 \mathrm{~min}$ & $60 \mathrm{~min}$ & $90 \mathrm{~min}$ \\
\hline $\mathrm{Pb} \%$ & 92,3 & 95,6 & 96,4 \\
\hline Leachate,g/l: & & & \\
\hline $\mathrm{Pb} \ldots \ldots \ldots \ldots$ & 163,500 & 176,700 & 180,300 \\
\hline $\mathrm{H}_{2} \mathrm{SiF}_{6} \ldots$ & 62,900 & 55,400 & 52,300 \\
\hline Zn........... & 0,540 & 0,619 & 0,683 \\
\hline Fe............ & 0,369 & 0,415 & 0,091 \\
\hline $\mathrm{Cu} . . . . . . . .$. & 0,050 & 0,091 & 0,109 \\
\hline Сo........... & 0,006 & 0,007 & 0,007 \\
\hline $\mathrm{Ni} . . . . . . . . .$. & 0,012 & 0,014 & 0,007 \\
\hline
\end{tabular}

\begin{tabular}{|c|c|c|}
\hline $\begin{array}{c}\text { Leach } \\
\text { temperature } \\
\mathrm{T}^{\circ} \mathrm{C}\end{array}$ & $\begin{array}{c}\text { Leach time, } \\
(\mathrm{min})\end{array}$ & $P b \%$ \\
\hline 50 & 335 & 62,3 \\
70 & 240 & 91,5 \\
80 & 90 & 76,0 \\
90 & 75 & 90,1 \\
90 & 90 & 97,5 \\
95 & 35 & 96,0 \\
95 & 75 & 96,5 \\
\hline
\end{tabular}

Table 3. Effect of leach time in Pb extraction

\begin{tabular}{|c|c|c|c|c|}
\hline & \multicolumn{4}{|c|}{$\mathrm{H}_{2} \mathrm{SiF}_{6}$-technical-grade acid } \\
\hline & $175 \mathrm{~g} / 1$ & $\begin{array}{c}200 \\
\mathrm{~g} / \mathrm{l}\end{array}$ & $\begin{array}{c}250 \\
g / 1\end{array}$ & $300 \mathrm{~g} / 1$ \\
\hline $\mathrm{Pb} \%$ & 89,0 & 97,5 & 95,4 & 95,7 \\
\hline : & 180 & 179 & 184 & 177 \\
\hline $\mathrm{Pb} \ldots \ldots \ldots \ldots$ & 32 & 56 & 94 & 133 \\
\hline $\mathrm{H}_{2} \mathrm{SiF}_{6} \ldots$ & 0,57 & 0,75 & 0,82 & 1,00 \\
\hline $\mathrm{Zn} . . . \ldots \ldots \ldots$ & 0,53 & 0,61 & 0,61 & 0,67 \\
\hline Fe........... & 0,12 & 0,13 & 0,13 & 0,18 \\
\hline $\mathrm{Cu} . . . \ldots \ldots . .$. & 0,00 & 0,00 & 0,00 & 0,00 \\
\hline Со............ & 0,02 & 0,02 & 0,02 & 0,02 \\
\hline Ni............ & & & & \\
\hline
\end{tabular}

Table 4. Effect of $\mathrm{H}_{2} \mathrm{SiF}_{6}$ concetration

The effect of using different combinations of oxidants of $\mathrm{H}_{2} \mathrm{O}_{2}$ and $\mathrm{PbO}_{2}$ on $\mathrm{PbS}$ leaching was insignificant. Previous leaching experiments showed that $\mathrm{H}_{2} \mathrm{O}_{2}$ was a more efficient oxidizer 
to initiate the leach reaction. Also, it was less expensive than $\mathrm{PbO}_{2}$. Thus, it is beneficial to use $\mathrm{H}_{2} \mathrm{O}_{2}$ to leach $\mathrm{PbS}$ and only use $\mathrm{PbO}_{2}$ at the end of the leach to void oxidizing $\mathrm{PbS}$ into $\mathrm{PbSO}_{4}$.

Leaching temperatures had a great influence on reaction rate and $\mathrm{Pb}$ extraction. When leaching below $80^{\circ} \mathrm{C}$, the reaction rate was thought to be too slow for any practical pplication. Lead extraction was $96 \%$ when leaching at $95^{\circ} \mathrm{C}$ for $35 \mathrm{~min}$ using $\mathrm{H}_{2} \mathrm{O}_{2}$ and $\mathrm{PbO}_{2}$ as oxidants. The leach-ing rate increased greatly and the required leaching time was reduced from $90 \mathrm{~min}$ to $35 \mathrm{~min}$ as the temperature increased from $90^{\circ} \mathrm{C}$ to $95^{\circ} \mathrm{C}$. Lead extraction was increased from $92 \%$ to $96 \%$ as leaching time increased from $30 \mathrm{~min}$ to $60 \mathrm{~min}$ at $95^{\circ} \mathrm{C}$. Initial leaching was rapid, but the elemental sulfur formed and coated the $\mathrm{PbS}$ particles, further reaction was probably diffusion controlled and the leach rate was reduced. However, the efect of the sulfur coating was not critical, because of the fine particle size of the $\mathrm{PbS}$.

The amounts of $\mathrm{PbS}, \mathrm{PbO}_{2}$ and $\mathrm{H}_{2} \mathrm{SiF}_{6}$ used in a leach test determined the concentration of $\mathrm{PbSiF}_{6}$ and free $\mathrm{H}_{2} \mathrm{SiF}_{6}$ in the pregnant leachate. Increasing the concentration of free $\mathrm{H}_{2} \mathrm{SiF}_{6}$ above $60 \mathrm{~g} / \mathrm{lit}$ had no significant effect on the $\mathrm{Pb}$ extraction, extraction of impurities decreased with decreasing concentration of free $\mathrm{H}_{2} \mathrm{SiF}_{6}$. Lead extraction of $96 \%, 91 \%$ and $96 \%$ were achieved using $\mathrm{H}_{2} \mathrm{SiF}_{6}$ solutions made from technical-grade, waste, and recycled acid. Waste $\mathrm{H}_{2} \mathrm{SiF}_{6}$ contained $\mathrm{HCl}$ and $\mathrm{H}_{2} \mathrm{SO}_{4}$ as impurities, which formed some insoluble $\mathrm{Pb}$ salts during leaching, resulting in lower $\mathrm{Pb}$ extraction. Recycled electrolyte, in which impurities were removed during prior leaching, was as reactive as technical-grade $\mathrm{H}_{2} \mathrm{SiF}_{6}$.

\section{Experimental tests}

The conditions by the leaching process of the synthetic galena mixures $(P b S)$ with gangue mineral's compounds $(\mathrm{ZnS}, \mathrm{CuS}, \mathrm{NiS}, \mathrm{CoS}, \mathrm{CaO}$, $\mathrm{MgO}, \mathrm{Fe}_{2} \mathrm{O}_{3}, \mathrm{SiO}_{2}$ ) and oxidants addition $\mathrm{H}_{2} \mathrm{O}_{2}$ and $\mathrm{PbO}_{2}$, leaching temperature $\left({ }^{\circ} \mathrm{C}\right)$ with retaining leaching time $(\mathrm{min})$ in the presence of technical $\mathrm{H}_{2} \mathrm{SiF}_{6}$ is shown on the following tables.

Table 5. Chemistry composition of the synthetic mixures

\begin{tabular}{|c|c|c|c|}
\hline \multirow{2}{*}{ Compounds } & \multicolumn{3}{|c|}{ Synthetic mixures } \\
\cline { 2 - 4 } & I & II & III \\
\hline $\mathrm{Pb}$ & 50.000 & 60.000 & \\
\hline $\mathrm{PbS}$ & 57.740 & 70.000 & 80.830 \\
\hline $\mathrm{ZnS}$ & 5.000 & 5.000 & 5.000 \\
\hline $\mathrm{CuS}$ & 1.000 & 1.000 & 1.000 \\
\hline & 0.050 & 0.050 & 0.050 \\
\hline $\mathrm{Fe}_{2} \mathrm{O}_{3}$ & 1.010 & 1.050 & 1.020 \\
\hline $\mathrm{SiO}_{2}$ & 29.200 & 16.900 & 6.100 \\
\hline $\mathrm{Al}_{2} \mathrm{O}_{3}$ & 2.000 & 2.000 & 2.000 \\
\hline $\mathrm{CaO}$ & 2.000 & 2.000 & 2.000 \\
\hline $\mathrm{MgO}$ & 2.000 & 2.000 & 2.000 \\
\hline $\mathrm{Total}$ & 100.000 & 100.000 & 100.000 \\
\hline \multicolumn{4}{|l}{} \\
\hline
\end{tabular}

Table 6. Effect of various amounts of oxidants

\begin{tabular}{|c|c|c|c|}
\hline $\begin{array}{c}\text { Test } \\
(P b-70 \%)\end{array}$ & $\begin{array}{c}\mathrm{H}_{2} \mathrm{O}_{2-} \\
35 \% \\
\mathrm{ml}\end{array}$ & $\begin{array}{c}\mathrm{PbO}_{2}, \\
\mathrm{gr}\end{array}$ & $\begin{array}{c}\mathrm{Pb} \\
(\%)\end{array}$ \\
\hline \hline 1 & 0,0 & 15,0 & 90,0 \\
2 & 2,5 & 15,0 & 95,0 \\
3 & 5,0 & 9,5 & 95,0 \\
4 & 7,5 & 8,0 & 96,5 \\
5 & 10,0 & 5,0 & 95,0 \\
6 & 19,0 & 0 & 96,0 \\
\hline
\end{tabular}

Table 7. $35 \% \mathrm{H}_{2} \mathrm{O}_{2}(7,5 \mathrm{ml}) ; \mathrm{PbO}_{2}(8 \mathrm{gr})$

\begin{tabular}{|c|c|c|c|c|}
\hline & \multicolumn{4}{|c|}{$\mathrm{H}_{2} \mathrm{SiF}_{6}$} \\
\hline & $\begin{array}{l}175 \\
g r / l\end{array}$ & $\begin{array}{c}200 \\
g r / l\end{array}$ & $\begin{array}{l}250 \\
g r / l\end{array}$ & $\begin{array}{l}300 \\
g r / l\end{array}$ \\
\hline$P b(\%)$ & 85,0 & 97,5 & 95,0 & 95,5 \\
\hline $\begin{array}{l}\text { Analysis of } \\
\text { leachate, } g r / l\end{array}$ & & & & \\
\hline$P b \ldots \ldots \ldots . . .$. & 180 & 175 & 185 & 175 \\
\hline $\mathrm{H}_{2} \mathrm{SiF}_{6 \ldots .}$ & 30 & 55 & 90 & 130 \\
\hline Zn........... & 0,55 & 0,75 & 0,80 & 1,00 \\
\hline$F e \ldots \ldots \ldots . . .$. & 0,50 & 0,60 & 0,60 & 0,65 \\
\hline$N i \ldots \ldots \ldots \ldots$ & 0,10 & 0,10 & 0,10 & 0,2 \\
\hline Си.......... & 0,015 & 0,02 & 0,02 & 0,02 \\
\hline
\end{tabular}

Table 8. $35 \% \quad \mathrm{H}_{2} \mathrm{O}_{2}(7,5 \mathrm{ml}) ; \mathrm{PbO}_{2}(8 \mathrm{gr})$; $\mathrm{H}_{2} \mathrm{SiF}_{6}(200 \mathrm{gr} / \mathrm{l})$

\begin{tabular}{|c|c|c|c|}
\hline $\mathrm{Pb} \%$ & $\mathrm{~T}^{\circ} \mathrm{C}$ & $t(\mathrm{~min})$ & $\mathrm{Pb} \%$ \\
\hline \hline
\end{tabular}




\begin{tabular}{|c|c|c|c|}
\hline $50 \%$ & $\begin{array}{l}70 \\
80 \\
90\end{array}$ & $\begin{array}{l}30 \\
60 \\
90 \\
30 \\
60 \\
90 \\
30 \\
60 \\
90\end{array}$ & $\begin{array}{l}52,5 \\
56,5 \\
65,3 \\
54,2 \\
58,5 \\
67,0 \\
56,5 \\
59,1 \\
70,0\end{array}$ \\
\hline $60 \%$ & $\begin{array}{l}70 \\
80 \\
90\end{array}$ & $\begin{array}{l}30 \\
60 \\
90 \\
30 \\
60 \\
90 \\
30 \\
60 \\
90\end{array}$ & $\begin{array}{l}55,6 \\
60,2 \\
68,7 \\
57,2 \\
63,3 \\
71,5 \\
57,0 \\
61,0 \\
73,5\end{array}$ \\
\hline $70 \%$ & 80 & $\begin{array}{l}30 \\
60 \\
90 \\
30 \\
60 \\
90 \\
30 \\
60 \\
90\end{array}$ & $\begin{array}{l}60,5 \\
63,8 \\
75,0 \\
65,0 \\
72,0 \\
79,0 \\
87,6 \\
95,3 \\
97,6\end{array}$ \\
\hline
\end{tabular}

\section{Conclusions}

Above mentioned combined hydrometallurgical and electrometallurgical methods are de- veloped to produce lead and elemental $S$ from synthetic mixures or concentrates with high purity. Contemporary, this process eliminates $\mathrm{S}$ gases and $\mathrm{Pb}$ emissions. The elemental $\mathrm{S}$ produced is easier to transport and store than is the $\mathrm{H}_{2} \mathrm{SO}_{4}$ generated by the pyrometallurgical methods.

Investigated experiments and tests included oxidative leaching of $\mathrm{PbS}$ in synthetic mixures with $\mathrm{H}_{2} \mathrm{SiF}_{6}$, electrowinning the leach solution to produce high-purity lead metal, carbon treatmet of spent electrolyte for recycling, and $S$ removal from the leach residue. Investigated experiments by $\mathrm{PbS}$ synthetic mixures show satisfactory $\mathrm{Pb}$ extraction and appropriate possibility for treatment of natural ore samples and concentrates produced in industrial mineral processing lead-zinc plants in the Republic of Macedonia.

\section{References}

1. Cole, E.R. (1985). Production of Lead from Sulfides. U.S. pat. 4,500,398.

2. Cole, E.R. (1985). Update on Recovering Lead from Scrap Batteries. Journal Metall., vol 37, pp 79-83.

3. Cole, E.R. (1985). Recovery of Lead from Battery Sludge. Journal Metall., vol 35, pp 4246.

4. Haver, F.P. (1970). Recovery of Lead and Sulfur from Galena Concentrate Using a Ferric Sulfate Leach. BuMines RI 7360, pp 13.

5. Lee, A.Y. (1984). Electrolytic Method for Recovery of Lead from Scrap Batteries. BuMines RI 8857, pp 20.

6. Lee, A.Y. (1986). Hydrometallurgical Process for Producing Lead and Elemental Sulfur from Galena Concentrates. BuMines RI 9055, pp 13.

7. Wong, M.M. (1983). Integrated Operation of Ferric Chloride Leaching, Molten-Sat Electrolysis Process for Production of Lead. BuMines RI 8770, pp 21. 


